\title{
THE IMPACT OF EU IMMIGRATION ON ECONOMIC GROWTH THROUGH THE SKILL COMPOSITION CHANNEL
}

\author{
Andreea Claudia ȘERBAN ${ }^{1}$, Mirela Ionela ACELEANU², \\ Andrei Silviu DOSPINESCU ${ }^{3}$, Diana-Mihaela T,ÎRCA ${ }^{4^{*}}$, \\ Isabel NOVO-CORTI ${ }^{5}$
}

1,2Department of Economics and Economic Policy, Faculty of Theoretical and Applied Economics, The Bucharest University of Economic Studies, Romana Square, No. 6, 010374 Bucharest, Romania ${ }^{3}$ Centre for Industry and Services Economics, "Costin C. Kiritescu" National Institute for Economic Research, Romanian Academy, Calea 13 Septembrie No. 13, District 5, 050711 Bucharest, Romania ${ }^{4}$ Department of Economics and Business Administration, Faculty of Economics, "Constantin Brâncuşi" University of Târgu-Jiu, Tineretului Street, No. 4, Târgu-Jiu, Gorj, Romania

${ }^{5}$ Economic Development and Social Sustainability Research Group (EDaSS), Department of Economic Analysis and Business Administration, Faculty of Economics and Business, Universidade da Coruna, A Coruña 15071, Spain

Received 06 October 2019; accepted 20 October 2019

\begin{abstract}
The paper aims to examine the new trends of immigration and their implications on the economy of the host country, particularly on economic growth and unemployment. As the effects of aging population can be felt in many countries, especially in developed ones, migration will continue to play an increasing role in the economic growth of all countries, either sending or receiving. Given the changes in migration trends and migration policies, the impact of the process should be revised. One of the main characteristics that significantly impacts economic growth is the education and skill level of immigrants. In the light of this fact, the research aims to identify the impact of immigration on growth through the skill composition channel. We analyzed the impact of skilled and unskilled immigration on growth, also including the unemployment rate as a relevant factor for the labour market. We estimated six dynamic panel models using the system of generalised method of moments (GMM) to take into account the risk of an endogeneity bias of the migration variables. The results indicate a positive and significant effect of skilled immigration on the economic growth of the receiving country. The results also point to a 1.3 percent $\beta$-convergence rate consistent with the values found in the convergence literature which are around 2 percent.
\end{abstract}

Keywords: migration, immigration, labour market, unemployment, European Union.

JEL Classification: F22, O15, J61.

${ }^{\star}$ Corresponding author. E-mail: diana.pociovalisteanu@gmail.com

This is an Open Access article distributed under the terms of the Creative Commons Attribution License (http://creativecommons. org/licenses/by/4.0/), which permits unrestricted use, distribution, and reproduction in any medium, provided the original author and source are credited. 


\section{Introduction}

The attitude towards immigration has changed over time in Europe. Europe has a long history of internal migration flows that varied in response to the shifts of economical and political power in Europe. There are many factors that drive the attitude towards migration: the heterogeneity in individual characteristics, country characteristics, the role of regions within countries (Markaki \& Longhi, 2012; Rica et al., 2013) and, recently, climate change impact, extreme climate events or weather and environmental degradation (Wilkinson et al. 2016; European Commission, 2017; Lu et al., 2018). After liberal policies, until the seventies, the restrictive policies that followed were gradually liberalised. The free movement of goods and services is recognised in the European Union, thus in the present societies the migration cannot be seen as an alternative to the rising of protectionism, or vice versa, as it was happening after the Second World War (Bhagwati, 1982). This was due to the fact that immigration acts like trade, because the immigrants move from the countries with low income and productivity to countries with higher productivity and, as a result, with higher income, causing the increased allocative efficiency of labour in a specific geographical space (Centre for Economic Performance London School of Economics, 2016).

The fastest changes in terms of migration started in 1990, after the falling of socialism. The development of the Southern European countries has made them attractive for immigrants and the countries from the core of the European Union started to consider the possibility of attracting immigrants with a high level of education or with the necessary skills for the changing economy (Popescu et al., 2017). The economic transition of the excommunist countries, the ethnic conflicts, the integration of several new countries in the European Union have all led to the structure and direction of migration flows in the EU (Dobson \& Sennikova, 2007; Bonifazi et al., 2008; Dustmann \& Frattini, 2013).

The free movement of people, as part of European Union single market, determined the increasing immigration flow in the European Union, which raised questions again, especially after 2004-2007, about the costs and benefits of immigration. The enlargement of the European Union has led to the necessity of adopting measures referring to immigration for the harmonisation of this process. The free movement of people can also bring security risks, while reducing or removing them depends on the cooperation between states, concerning the access to information or intelligence gathering. The effects of immigration are analysed more rigorously as a result of the higher flows of immigrants from the new countries that joined the European Union and, lately, as a result of the new increased flow of refugees. Furthermore, the terrorist attacks have shown that, at the European Union level, the migration and integration must be approached together, in order to maintain the security of the host country. Integration has become not only a social necessity, but also a normality in the multicultural civilisations (Bonifazi et al., 2008). Restoring borders, as a response to security and economic risks, will question the idea of united Europe, will limit the rights of citizens and will negatively affect the economic post-crisis recovery (European Movement International [EMI], 2016a, 2016b).

The globalisation of the labour market is different from the globalisation of other markets e.g. capital, goods and services, due to the specificity of the 'goods' that are transacted. Migration represents the movement of labour across borders, responding to the market signals and, 
as a result, influencing the labour supply and demographic features, not only in the sending country, but also in the host country (Chiswick \& Hatton, 2003; Bratsberg et al., 2014; Bell et al., 2016).

The self-selection is more favourable for the labour market for economic immigrants, than for other people who move (the refugees) as a result of the fact that, generally, they are more motivated, more ambitious, more entrepreneurial, not only compared to those who leave the country for other reasons, but also compared to the people who do not leave it. The more favourable the selection of migrants is, the more successful their integration will be and, as a result, the positive effect on the host country is larger (Chiswick, 2000; Borjas, 1987; Bilan, 2012). Even it would represent a favorable aspect both for sending and receiving country, the entrepreneurial potential of immigrants is poorly and limited by lack of financial resources, bureaucracy or regulations on business start by immigrants (Dinu et al., 2015).

On the basis of the qualitative approach regarding the "for" and "against" migration policies, the paper quantitatively analyses the immigration in the European Union and its implications on the host country, especially on growth, unemployment and income level through the skill composition channel. The objective of this paper is to examine the impact of immigration on the economic growth of the host country, from the perspective of skills endowment, also taking into account relevant factors for the labour market.

\section{Immigration's impact on growth through the skill composition channel. Literature review}

Immigration has been an important issue for economic development given the effects on unemployment and income level and through these on economic growth. Immigration enables individuals to better respond to job opportunities and skill shortages over both the short and long term (Newbold, 2019). Even if the characteristics of immigrants and their possibilities of integration differ significantly from country to country, the process has raised questions about the economic performance of the immigrants and the successful strategies of the host countries to ensure the economic assimilation of immigrants, but also about the economic consequences of immigration for the host economies. Based on many studies, Rica et al. (2013) concluded that here is little evidence of a detrimental effect of immigration on the economies of the host countries. Dustmann et al. (2008) suggest that the impact of immigrants on the host countries depends on the skills of immigrants relative to the skills of native population and if there are differences in skill composition of the two groups the adjustment will use wages.

The impact of immigration on economic growth considering the skills and educational attainment is debated in some empirical studies. Due to the lack of availability of harmonised data on migration considering skill's channel, there are few empirical studies analysing the impact of immigration on growth considering skill endowment. The need for these analyzes is more important as the characteristics of immigrants have changed in the current period compared to the previous decades in terms of education and skill level.

The skill level of immigrants is one of the main channels through which migration impacts growth (McCann, 2001; Nijkamp \& Poot, 1998). Several studies (Kanbur \& Rapoport, 2005; Rappaport, 2005) showed that skill-selective mobility has a significant impact on both 
the origin and destination countries. In this respect, migration affects the ratio between skilled and unskilled workers. Moreover, the inflow of skilled labour can generate an upward shift in the productivity of the receiving country (Etzo, 2008; Borjas, 1999b; Andersen \& Dalgaard, 2011) and can have a positive effect on innovation, even it differs across industries (Fassio et al., 2019). In the same vain, the mobility of the labour force, entails workers will aim at maximizing their individual utility and move to countries and regions with greater opportunities. This will lead to increased disparities between countries and regions with the receiving countries growth benefitting from the inflow of skilled immigration (Fratesi \& Riggi, 2007).

Recent research shows that a greater cross-border mobility contributes to higher global long-run growth. Migrants can influence productivity growth, both in the receiving and sending countries through several channels, such as skill and diversity spillovers, remittances, age structure, entrepreneurial skills (Brunow et al., 2015; United Nations, 2011). Also, higher rates of migrants with management skills can positively influence foreign direct investments in receiving country (Cuadros et al., 2019).

Immigrants bring their skills and abilities to the receiving country enhancing the stock of human capital. This is one main channel through which immigration impacts growth (Figure 1). Given the close relation between the skill level on one hand and economic growth and the labour market variables on the other we have looked at the impact of migration variables on growth, unemployment and income level. We have also controlled for the structural characteristics of the receiving country and considered the skill composition and skill gap of the population.

The immigration of skilled workers represents a transfer of human capital between countries and regions, that implies a portability of human capital acquired in their country of origin. This is a disadvantage for the sending countries, as they invest in education for national population and they do not obtain a positive return to their investments. As indicated in literature, this advantage is not fully transferred to the host countries. There is an imperfect portability of human capital between countries, which generates low labour market integration and initial low earnings for immigrants in the host country. These are reflected in the inequality of income distribution between nationals and non-nationals and in the increased risk of poverty or social exclusion for immigrants. The level of transferability of human capital depends on geographic origin, countries with a similar culture of language or highly developed countries having greater rates of transferability (Sanroma et al., 2015; Warman et al., 2015).

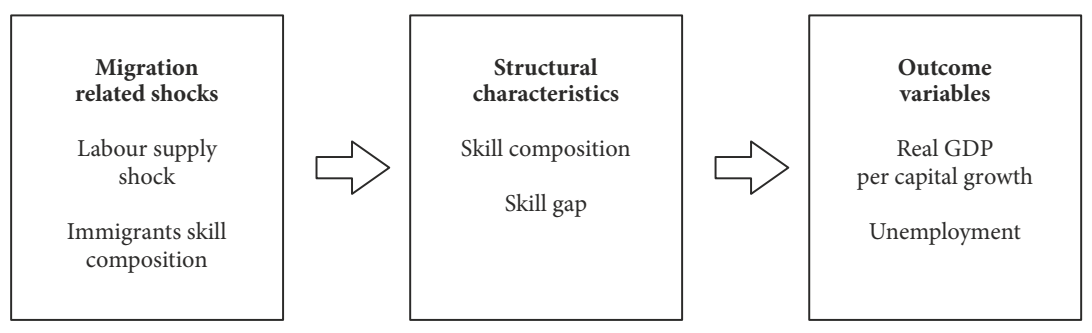

Figure 1. Analyzed transmission channels 
Immigrants are more likely to be overeducated than the native population. Immigrants are not able to use their skills, knowledge, education or labour market experience due to the duality of the labour market and the lack of employment opportunities for non-nationals and, under these circumstances, they accept jobs under their level of education (Green et al., 2007). Moreover, the origin of human capital is a determinant for its value: the education and labour market experience acquired in the origin country is significantly less valued that the human capital obtained in the receiving country. In order to increase the return to education acquired in the sending country, the immigrants should acquire additional education after immigration (Friedberg, 2000). The necessity of new acquisitions could be explained by the differences in the educational systems from the sending and receiving country in terms of theoretical or practical background, the educational infrastructure or the public and private investments in the field.

The immigrants represent a challenge for the host country. It is often considered that low skilled workers are the ones who cause negative effects on the national economy of the host country, as they need to be supported, trained, integrated into a new labour market, the one of the host country. These effects are the result of the changes in today's economy, which is no longer based on work in labour-intensive sectors and where the goods and services are free to move (Bhagwati, 1982; Mandelman \& Zlate, 2017). Generally lower than the nationals, the income of immigrants is different from the income of natives and it is also different among immigrants with the same level of education or skills depending on the economic and political conditions from the sending country from the moment of migration (Borjas, 1987; Roman \& Voicu, 2010).

The integration of immigrants also depends on how they adapt to the culture of the host country. Both immigrants and the host country must accept cultural diversity. Studies show that the integration of immigrants in the host country, from the cultural point of view, if it cannot be done after 2-3 generations, it transforms in some kind of cultural separation which implies that immigrants largely keep their culture, customs, religion. Smaller minorities assimilate culturally faster and easier. Currently, confronting cultural diversity in European societies is one of the most important challenges for governments and civil society. Social and cultural interactions are determining factors in the socio-economic integration of immigrants, which significantly affect the labour market. As result, some specialists draw attention to the need to develop social policies that facilitate contacts across communities, promote tolerance, trust, and respect towards other groups, so as to contribute to the development of a new national identity (Algan et al., 2013).

Studies on the impact of the cultural diversity of the migrants from the European countries on the economic growth of the USA, during the age of mass migration (1870-1920), show a direct relation between the two factors. Thus, a greater diversity of population, through the increase of cultural fractionation, has led to an increase in per capita productivity, due to greater variety of workers' skills (Ager \& Bruckner, 2013).

Alesina et al. demonstrate in an empirical study, that the birthplace diversity is an important determinant of economic prosperity. They show that the productive efects of birthplace diversity is largest for immigrants originating from richer countries and the increasing of the diversity of skilled immigration by one percentage point increases long run economic output by about two percent (Alesina et al., 2016). 
The human capital and dual labour market theory can both explain the immigration phenomenon. Some authors (Blossfeld \& Mayer, 1988; Mihi-Ramirez et al., 2017) explain that the existence of duality on the labour market has no educational reasons. The human capital theory reveals that a person will have a job responding to his education and qualification and the developed countries could confront with a dual labour market: a sector with high income, secure jobs and work conditions and a second sector with low security and income. The existence of this duality allows attracting labour force from the less developed countries for the second sector, with worse working conditions, low incomes and high employment fluctuations. This sector is less attractive for national population, even in the case of high national unemployment rates, as the case of Southern European countries. The possibility of moving between the two sectors is reduced, especially for the ones with low level of education or inappropriate qualifications for the labour market. The sector is still attractive for women, students or young people without experience and, also, for immigrants. Moreover, the immigrants having the above characteristics are less flexible and more probably would not claim for good job conditions and high income (Doeringer \& Piore, 1971; Piore, 1979; Ogawa \& Tsubuku, 2017).

Kalaitzidakis et al. (2001) analyse the relationship between human capital accumulation and economic growth and show that this relation is very complex and differs according to some factors: the country's level of human capital, the way in which the human capital affects economic growth and the absorption of new technologies.

The lack of compatibility between qualification of migrants and national population determines the participation of immigrants in a specific sector, which can be a form of discrimination on the labour market, thus the participation in a specific sector is difficult to be attributed to low education, lack of experience or low mobility of immigrants (Bonifazi et al., 2008). The high rates of immigrants can determine, also, the discrimination on the labour market due to employer preferences for native workers, backed up by rules or high rates of immigration which leads to extended possibilities of choosing (Mueller, 1999).

The need of cheap and unqualified labour has determined the acceptance of immigrants from the Southern European countries in Western Europe. The immigrants from the Eastern Europe, although young and highly educated, could accept jobs under their level of qualification, hard work conditions and low income in sectors as agriculture, constructions, elderly care (Favell, 2008). One example is the German-Polish agreement of acceptance for Polish immigrants as seasonal workers in Germany. Although they represented less than $3 \%$ from the labour force, their share in the seasonal agricultural labour force was almost $90 \%$. The attempts to motivate the national labour force in order to accept seasonal jobs have been mostly a failure, because the agricultural jobs were considered degrading, dirty, dangerous, they needed good health conditions (Bonifazi et al., 2008). Similar situations have been in Spain and Italy with Romanian immigrants in agriculture.

Some authors (Kemnitz, 2003) consider that the effect of immigration is different in the case of low or highly skilled workers, thus depending on the production structure in the host country. In the case of low skilled workers, easily substitutable, immigration reduces unemployment. Also, they sustain low-cost manufacturing and services industries by reducing firms' incentives to invest in training (Coulter, 2018; Wadsworth, 2015). The effects are reversed in the case of highly skilled workers with high income demands, affecting the welfare 
of low skilled native workers. From this point of view, the preference for migration of highly skilled workers should be carefully approached. The effect of migration of this category is double: in the sending country there are losses of tax contributions, and in the host country there are budget spending as a result of the increase of low skilled workers unemployment. The impact of immigration on the public finances is also different due to other aspects: the nature of rules regarding taxes, the way immigrants are chosen, the phase of the business cycle (Preston, 2013; Naumann et al., 2018). In order to reduce the financial burden, the country's policies regarding the immigrants can limit the access of low skilled immigrants from certain countries or can follow a faster policy integration of immigrants (Gathmann, 2015). Other authors (Constant, 2014) consider that, in the long term, both skilled and unskilled immigrants stimulate job creation in host country by increasing production, selfemployment, entrepreneurship and by providing opportunities for native workers to increase their skill's level leading to more efficient production and economic growth. Even if Lofstrom (2014) considers that immigrants are more entrepreneurial and the business ownership contributes to economic integration, he supports the policies targeting high-skilled immigrants rather than policies focused on entrepreneurship, as education is found to be a predictor of immigrant success.

Using cross-sectional country data, Felbermayr et al. (2010) had estimated the effects of immigration on real per-capita income, finding a non-negative effect of immigration in percapita income. Dolado et al. (1994) analyzed the effects of immigration in a Solow growth model, augmented by migration and human capital. They debated on how different the effects of immigration can be considering the human capital brought and they showed that the negative effects on immigration tends to decrease the higher the immigrant's human capital. Orefice (2010) investigated the effects of immigrants and their skill level on the host countries' income variation. Using a panel data model, he provided evidence of the positive effects of being skilled on per capital GDP, supporting through this result the skill selective immigration policy in order to increase the share of unskilled over skilled immigrants.

Bodvarsson and Van den Berg (2013) draw attention to the need to analyse immigration not only from the point of view of the simple labour market model, which takes into account only aspects related to the earnings of immigrants, their well-being, the increased production, the rise of wages in the sending country and the decrease of wages in the receiving country. Thus, factors such as the consumer role of immigrants, not only that of producers, and also their role of innovators, inventors and entrepreneurship must be taken into account. Immigrants can contribute to the stimulation of technological progress in receiving countries, by facilitating the transfer of technology, contribution to innovation as entrepreneurs and workers in innovative activities, changing the size of economies and increasing the innovative competition.

Countries can influence the selection process through the immigration policies they adopt. Lately, many countries have already adopted skills-based migration programmes, offering priority to highly educated people. Having as examples traditional receiving countries (United States, Canada etc.) EU member states adopted migration programmes to attract highly skilled immigrants (Austia, United Kingdom) (Boubtane et al., 2014), generating losses of skilled migrants by non-EU states (Burzynski, 2018). Grossmann (2016) showed that immigration policies have to take into account how the process affects investment be- 
haviour and productivity, and how these aspects vary with migration type. He found that highly skilled immigration attracts foreign direct investments, increase per capita income and positive effects on labour productivity. The selective immigration policies in host countries cause potential brain drain in developing economies which conflict with development goals of leaving countries. By using a dynamic panel data model, Andersen and Dalgaard (2011) suggest positive effects on productivity in host country as result of greater interaction. If the labour market is rigid in the host country the productivity gains from immigration will be lower (Peri, 2014). The author also discussed the effects of immigration on less educated native workers, considering there is little evidence of immigration lowering wages of this category of natives.

Also, social protection can influence the migration process, attracting immigrants depending on their generosity. Studies have shown that immigrants are more concentrated in the states that offer generous benefits and, as a result, the degree of participation to welfare systems are more sensible to changes in these benefits compared to the national population (Borjas, 1999a; Josifidis et al., 2014; Fuest \& Thum, 1999). When conditions change unfavorably for migrants, the migration flows redirect to countries with greater opportunities on the labour market and more generous social protection systems (Kahanec \& Kurekova, 2014).

Even if countries with generous social protection system attract immigrants with higher demand for such services, the highly skilled immigrants are chosen from those with low demand for public services, even in the states with solid social protection. Studies on countries with most generous social protection systems in the world, have revealed that highly skilled immigrants have a positive effect on the state budget, because although they pay less than the national citizens, they demand less public services, which confirms the hypothesis that are selected, even in the states with great social protection, among those who have a low demand for social protection (Bødker et al., 2013). As the immigrants represent a non-homogeneous group in terms of age, education and experience, the total effect on the public finance in the host countries is reduced and sometimes ambiguous (Borjas, 1999a).

\section{Immigration process in European Union}

Labour mobility is an important adjustment mechanism in the European Union labour market (Kahanec \& Kurekova, 2014). Individuals have many reasons to migrate. Generally, searching for better economic and social opportunities, they tend to migrate to accumulate different types of capital e.g. knowledge, skills, competencies, experience, savings etc., to help them achieve different types of actions that they are interested in in the future (Kumpikaite \& Zickute, 2012). According to certain characteristics, opportunities to migrate or migration period may be different.

Economic and political interdependence that characterises today's world leads to global effects concerning immigration (and also refugees). Although the process must be considered at European level, each country has its own attitude toward these processes. The main vectors that attract immigration towards EU are the access to high quality services, the economic prosperity and the political stability inside the European Union borders. Inside EU, an important aspect that should be considered as reason for migration are the differences 
between economic development and policies adopted (Ozgen et al., 2009). A low level of real convergence in all economic and social areas generates asymmetric shocks resulted primary from the low correlation of the business cycles within EU, which affects macroeconomic stabilisation and, as a result, the labour market (Dinu et al., 2012).

Immigrants are more vulnerable in terms of their economic and social integration in the host countries. Studies show that the effects of naturalisation are significant and higher for the first generation of immigrants, in terms of earnings and job stability. Uncertainty is related to the causal relationship between naturalisation and integration success, because it is possible for immigrants with high chances of success to be naturalised. The effects of naturalisation are related to the fact that it opens the access of immigrants to public sector jobs. Employers are reluctant to hire and specialise immigrants if they know that their stay is temporary. Also, revenues increase as the number of years lived in a country increase (Gathmann, 2015; Dustmann \& Gorlach, 2016).

Difficulties relating to the integration of immigrants have increased as their share in the total population of the host country has raised. In 2017, immigrants from the European Union represented $3.31 \%$ of the total EU population while non-EU citizens represented $4.22 \%$ of the total EU population. The countries with the highest rates of EU migrants in total population are Ireland (8.9\%), Belgium (7.8\%), Austria (7.5\%), UK (5.5\%) and Germany (4.8\%) (Figure 2).

As European Union countries account for $44 \%$ of total EU immigration stock in 2017, there were near 17 million EU immigrants. The immigrants prefer countries with high development level and relatively low inequality of income distribution or generous social protection systems (Figure 3). Statistical data shows that immigrants are attracted to countries with relatively low rates of poverty or social exclusion but, considering the country specific

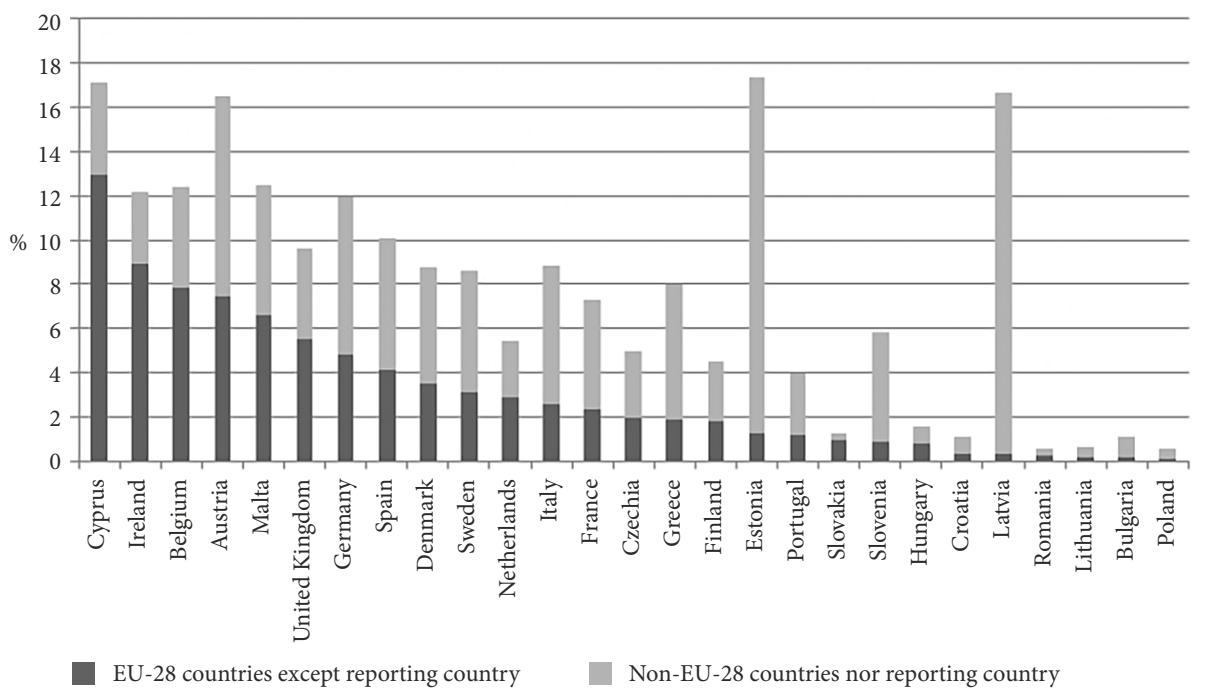

Figure 2. Share of immigrants (EU, Non-EU) in total population in EU countries, 2017 (source: computation based on Eurostat Statistics, 2019) 


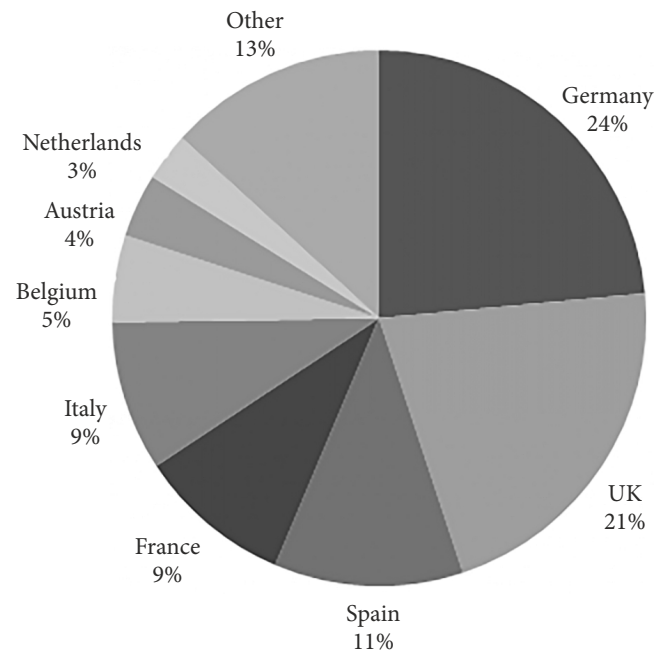

Figure 3. Immigration shares across EU countries

(EU-28 except reporting country), 2017

(source: computation based

on Eurostat Statistics, 2019)

policies, this is not an essential aspect of choosing the destination. Thus, countries with low rates of poverty, like Belgium or Austria (17.8\% and $13.5 \%$ in 2017) account for a smaller share of the EU migrants compared to United Kingdom, Spain or Italy, countries with higher rates of poverty in the same period $(21 \%$, $23.2 \%$ and $26.2 \%$ ). Poverty could be considered a reason for migration when we refer to the countries of origin of immigrants. These countries have higher rates of poverty compared not only to the receiving countries but also to other countries in the region (Romania and Bulgaria) (UN, 2011). Immigration has significant positive effects on poverty rates in the origin countries as an effect of monetary remittances (Peković, 2017), but studies show that immigration is also an efficient solution to reduce poverty in the receiving country. This is the result of prudent migration policies adopted traditionally which imply, on the one hand, attracting immigrants with certain demographic or educational characteristics and, on the other, selective limitative restrictions of brain drain (Oberman, 2015).

States and individuals consider immigration of unskilled workers the process that affects the period of the last years. Governments are trying to attract highly skilled immigrants because they pay higher taxes, have lower risk of becoming unemployed and generate positive externalities in production. Thus, the adverse effect of immigration on income inequality and overall discrimination is reduced, as it is very low for skilled workers (Müller, 1997).

At European Union level, EU immigrants are highly educated compared to national population. Thus, in $2017,31.2 \%$ of EU immigrants had tertiary education compared to the EU average of $28 \%$ of the total population. Even if it is not the subject of the study, we can note that the situation is different for non-EU immigrants, where the share of highly educated is lower than the EU average (Figure 4).

Governments concerned about income inequality will try to attract skilled immigrants without seeking to eliminate discrimination against workers with low skills if it expects them to return. Under these circumstances, immigration of low skilled workers is favourable to native population only if they return to their sending country. Otherwise, they gain the same rights as national population, situation in which a protectionist policy would limit the cost to the host country (Müller, 1997). Mihi-Ramirez et al. (2016) and Garcia-Rodriguez et al. (2015) consider that there exists a self selection of immigrants in highly developed countries where the greater degree of innovation and the prestige of academic institutions have a positive impact on the arrival of highly skilled immigrants. 


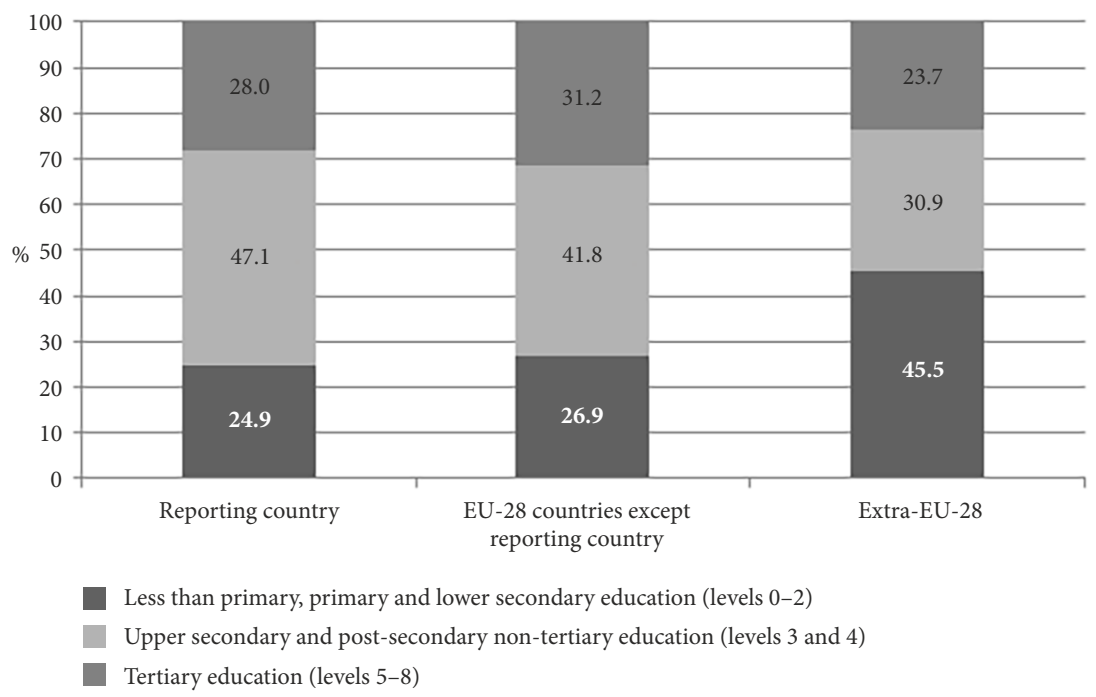

Figure 4. Population by educational attainment and citizenship, EU, 2017 (source: computation based on Eurostat Statistics, 2019)

The impact of immigration in the host country is different from country to country depending on its capacity to integrate immigrants and on many aspects such as the intensity of the phenomenon of immigration, the composition of the group, skills of migrants, their age and relationship with the labour market of the host country, the level of education, reasons for migration, the type of migration, permanent or temporary and the level of development and the host country's ability to integrate waves of immigrants.

Increasing the number of immigrants could harm national population as it can generate wage decrease due to increased labour supply. But, generally, wages are rigid to decrease, which means that the economy can be adjusted by other means, such as production structure or orientation to goods and services with higher productivity or increased trade. As labour force is larger because of immigration, companies will adapt their production to available skills and, as a result, revenue may increase. Social protection systems are burdened by large number of unemployed or inactive people and they are based on revenue collected from those who work. Although they earn low incomes, the activity and employment rates are higher for immigrants than for nationals, which means that the burden on social security systems does not increase due to immigration.

\section{Methodology, results and discussion}

\subsection{Data and methods}

Statistically delimitating migrants has significant consequence, impacting both the number and explanation of the implications of migration. There is no single definition of migrants. The definitions could refer to foreign birth, foreign citizenship, movement into another country for a different period of time. Also, migrants could include or not children, even if their 
parents are counted as migrants. Each of the three definitions has its limits: the first considers as migrants people who were born abroad but automatically became citizens of the country in which they now live (e.g. children born to armed forced personnel in working country), the second excludes nationals born abroad, but it also excludes people who have recently changed their country of residence and acquired the nationality of their new home country and the last poses problems of measurement (Sturge, 2018; Anderson \& Blinder, 2017).

Immigration from EU countries to one of other EU countries are defined according to European Union as the action by which a person establishes his or her usual residence in the territory of a EU member states for a period that is, or is expected to be, of at least 12 months, having previously been usually resident in another EU member state (Official Journal of European Union, 2007).

We have used into our analysis the definition of migrants that refers to foreign citizenship, irrespective of the age of the people or the period they are moving from leaving country. We have analysed the impact of migrants from the EU, so we referred to people having the citizenship of one of EU countries except reporting country. The analysis refers to all European Union member states, consequently we have used a set of 28 countries, all part of European Union between 2007 and 2017, including Croatia that became member in 2013 and United Kingdom that was still a EU member in 2017. We performed the analysis from 2007 until 2017, the last year with available data for all countries.

Based on data availability, we have started from 2007 when two new countries become EU member states: Romania and Bulgaria. Unlike the other former communist countries in Central and Eastern Europe, these two countries experienced significant developmental gaps, which forced their separate accession to the community bloc comparing to the other 10 countries (which joined EU in 2004). This new EU enlargement has significantly influenced the migration flows, both in volume and structure, as result of characteristics of these new countries,

Intraregional migration flows are very dynamic in the European Union. Opening borders as a result of the access to the single market of the European Union with free movement arrangements which include the freedom of movement of people has determined, starting with 2004 and 2007, changes in the migration flows to the old and developed countries of the EU. South-Eastern European countries have been, under these circumstances, countries of emigration, primarily to European Union, emigration flows being on a growing trend after the enlargements of 2004 and 2007 (International Organization of Migration, 2017).

After enlargement, in 2008 the collapse of investment house Lehman Brothers represented, both globally and at EU level, the start of the economic and financial crisis with deep effects on migration in response to global recession. This represented an important contextual factor for our analysis. Migrants are one of the most vulnerable categories of workers, which have experienced, in this context, changes in migration flows (Fix et al., 2009). Depending on the motivation and efforts made to migrate, the impact of the crisis on migration was different for both new migrants and those who have already left the country.

Castles and Vezzoli (2009) considered that the crisis reveals the interdependence of the world economy and especially of the global labour market for all skill levels. The results consist of reducing the migration flows from origin to destination countries. An increase in the 
propensity of migrants to return to their country of origin could be also notices as result of high unemployment rates in construction, manufacturing and services, branches with high migrant employment.

At European Union level there was a sharp increase in migration flows in 2007 followed by a decrease in 2008 and 2009 as a response to the economic crisis (Herm \& Poulain, 2012). Also, the patterns of EU immigration have changed, recording an increase of emigration from countries hardly affected by the crisis (Mol \& Valk, 2016). The gap in employment rates between migrants and nationals switch from negative to positive, indicating the increased vulnerability of immigrants in case of crisis. The migration flows increase again in 2012 and 2013 and started to slowdown from 2014 (European Investment Bank [EIB], 2016). The research methods used has both a qualitative and a quantitative approach. The study uses quantitative analysis using available data from official European Commission database, Eurostat, that are useful for identifying trends in immigration processes at European Union level. Quantitative data reflecting the current state of immigration was analysed in correlation with qualitative characteristics of immigrants.

We have used as main variables: real GDP per capita (chain linked volumes, 2010, euro per capita), immigration (\% of population having the citizenship of one of EU countries except reporting country in total population of reporting country), skilled and unskilled immigration (percentage of skilled/unskilled immigrants over total immigration) and skilled and unskilled population (percentage of skilled/unskilled population over total population). Data were taken from Eurostat Database (GDP) and OECD (International Immigration Database) and cover the period 2007-2017.

By skill composition channel analysis we referred to skilled or unskilled as result of schooling as this separation is more accurate than the one based on occupational structure, that could be more volatile. Skilled migration consists of people having tertiary education, as defined by International Standard Classification of Education (ISCED 5-8). Identifying skilled immigrants by schooling level implies some problems related to the imperfect portability of human capital or overeducation as we discussed in the previous sections. We have estimated six dynamic panel models using the system of generalised method of moments (GMM) to deal with the risk of an endogeneity bias. The fixed-effects IV estimators may suffer from the same bias issues as the OLS estimators (see Roodman, 2006). Given this, lagged values of the explanatory endogenous variable were used as instruments. This enabled control for the endogeneity and measurement error for the lag of the endogenous variable and the other explanatory variables.

The methodology employed in order to achieve the objectives mentioned above has involved a dynamic panel data model approach using system GMM estimators. We have considered two specification tests to ensure the consistency of the system of generalised method of moments estimator. The first one is the Arellano and Bond serial correlation test, which tests the null hypothesis of no first-order serial correlation and no second-order serial correlation in the residuals. The second one is the Sargan test of overidentifying restrictions, which examines the overall validity of the instruments by comparing the moment conditions to their sample analogue. 
The econometric specifications followed the standard approach of $\beta$-convergence. Following Sala-i-Martin (1996) we assumed a to be constant across economies and $\beta$-convergence to hold for all the economies in the panel.

$$
\ln \left(y_{i t}\right)=a+(1-\beta) \ln \left(y_{i, t-1}\right)+u_{i t},
$$

where $0<\beta<1$, and the errors $u$ have mean zero and finite variance.

Algebraic manipulations of Eq. (1) give us the equation form used in the estimations:

$$
\ln \left(\frac{y_{i t}}{y_{i, t-1}}\right)=a-\beta \ln \left(y_{i, t-l}\right)+u_{i t} .
$$

To Eq. (2) we have added a vector of explanatory variables to capture the impact of immigration variables on growth. The explained variable in Eq. (2) was represented by real GDP per capita growth (constant prices, reference year 2010). As explanatory variables we have used: the percentage of skilled and unskilled immigrants in total immigrants (SI) and (USI) respectively, the percentage of skilled population in total population (SP) and real GDP per capita with a lag (GDPpercapitat-1). To better understand the signs of the relation between skilled and unskilled immigrants on one hand and the real GDP per capita growth on the other we have also looked more closely to the unemployment rate (Ur) as a relevant factor. The indicators cover all EU member states and come from the Eurostat database.

\subsection{Results and discussion}

We have estimated six dynamic panel models using the system of generalised method of moments (GMM) to investigate the impact of immigration variables on growth and unemployment ${ }^{1}$. The GMM models passed the standard diagnostic tests. The p-values (please see the last three rows in the results tables below) indicate that the models are not overidentified and that there is no evidence of first-order autocorrelation at $5 \%$ level. The sign of the coefficients is in accordance with what is predicted in the literature. The t values indicate that the majority of the coefficients are significant.

We have run a GMM model to test the impact of skilled and unskilled immigration on growth. We have also controlled for the skill level of the population of the receiving country. The results (please see the Table 1 below) indicate that the coefficients for the skilled and unskilled immigration are significant at $1 \%$ and $5 \%$ level respectively. The sign of the coefficients shows the positive impact of skilled immigration on growth. The impact of the skilled population on growth is also positive indicating the role of the endowment with skills and abilities of the labour force in fostering economic growth. If we look at the historical migration flows, considering the skill level of the migrants we see that skill migration is growing while unskilled migration remains relatively constant. This reflects the transformation of the EU economies which increasingly depend on knowledge, information and high skill labour force. The $\beta$-convergence rate estimate is positive (see the functional form of Eq. (2)) and

\footnotetext{
${ }^{1}$ The models were estimated using Stata 15.
} 
Table 1. Testing the impact of skilled and unskilled immigration on growth based on a dynamic panel model ${ }^{1}$ Dependent variable: $\ln$ (gGDPpercapita) (source: author own calculation)

\begin{tabular}{|c|c|}
\hline $\ln \left(\right.$ GDPpercapita $\left.a_{t-1}\right)$ & $\begin{array}{c}-0.013^{\star * *} \\
(-4.84)\end{array}$ \\
\hline $\ln (S I)$ & $\begin{array}{c}0.012^{\star *} \\
(2.61)\end{array}$ \\
\hline $\ln (U S I)$ & $\begin{array}{c}-0.017^{* * *} \\
(-3.07)\end{array}$ \\
\hline $\ln (S P)$ & $\begin{array}{c}0.012 \\
(1.6) \\
\end{array}$ \\
\hline$P$-value for Arellano and Bond test for $A R(1)$ & 0.0 \\
\hline P-value for Arellano and Bond test for $A R(2)$ & 0.0 \\
\hline P-value for Sargan test & 0.0 \\
\hline
\end{tabular}

Legend: gGDPpercapita - Real GDP per capita growth; GDPpercapita - Real GDP per capita; SI - percentage of skilled immigrants; USI - percentage of unskilled immigrants; SP - percentage of skilled population.

Notes: ${ }^{1}$ Based on a dynamic panel data model using system GMM estimators.

$2 *,{ }^{* *},{ }^{* *}$ denote significance at $10 \%, 5 \%$ and $1 \%$ level, $\mathrm{t}$ statistics in parenthesis.

${ }^{3}$ The null hypothesis of the Arellano and Bond test is the absence of residual autocorrelation.

The results of the Arellano and Bond test indicate no first-order correlation at $1 \%$ level and no secondorder correlation at $1 \%$ level.

${ }^{4}$ The overidentification of the model was tested using the Sargent test and the null hypothesis was rejected at $1 \%$ level indicating the model is not overidentified.

significant. The result in Table 1 indicates a 1.3 percent convergence rate which is consistent with the values found in the convergence literature which are around 2 percent (Barro \& Sala-i-Martin, 1992; Mankiw et al., 1992; Sala-i-Martin, 1996; Armstrong \& Read, 2002; Rivas \& Villarroya, 2016).

Given the possible heterogeneity between the countries in the European Union we have also tested the convergence club hypothesis. We have splinted the countries in two clusters. The first cluster is represented by the EU15 countries which are more developed and attract the majority of the EU migration inflows and the second cluster represents the countries which joined the European Union after 2004. The EU15 cluster is extensively used by the Eurostat, the World Bank, OECD and other institutions to report various statistical data indicating the usefulness of using this as a criterion for splinting the countries in the sample. To further substantiate the grouping of the countries we have compared the kernel density estimates of real GDP per capita for the two groups. The distribution of the new member states displays higher average growth and are more shifted to the right compared with the EU15 countries' distribution (see Figure 5). To further check the significance of the difference between the distributions we have ran the Kolmogorov-Smirnov test. The null hypothesis of the equality of the distribution functions was rejected at the $10 \%$ level. The p-value for the combined Kolmogorov-Smirnov test was 0.07 and the D-Statistics was 0.367. 


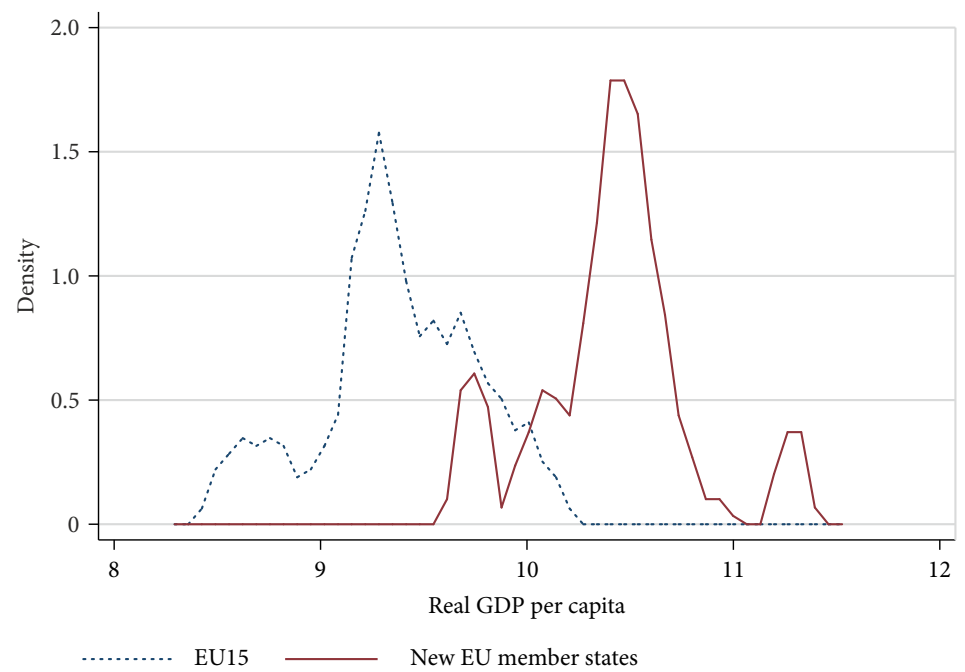

Figure 5. Comparative analysis of kernel density estimates distributions for countries in EU15 and new EU member states (source: computation based on Stata 15)

Table 2. Testing the impact of skilled and unskilled immigration on growth based on a dynamic panel model $^{1}$ for EU15 and the new EU member states (source: author own calculation)

Dependent variable: $\ln$ (gGDPpercapita)

\begin{tabular}{|l|c|c|}
\hline & EU15 member states & New EU member states \\
\hline $\ln \left(\right.$ GDPpercapita $\left._{t-1}\right)$ & $-0.014^{*}$ & $-0.022^{*}$ \\
& $(-2)$ & $(-1.91)$ \\
\hline $\ln (S I)$ & $0.019^{* *}$ & 0.0001 \\
& $(2.47)$ & $(-0.03)$ \\
\hline $\ln (U S I)$ & $-0.019^{* *}$ & -0.003 \\
& $(-2.22)$ & 0.008 \\
\hline $\ln (S P)$ & 0.006 & $0.8)$ \\
\hline P-value for Arellano and Bond test for AR(1) & $(0.74)$ & 0.006 \\
\hline P-value for Arellano and Bond test for AR(2) & 0.0 & 0.01 \\
\hline P-value for Sargan test & 0.0 & 0.02 \\
\hline
\end{tabular}

Legend: gGDPpercapita - Real GDP per capita growth; GDPpercapita - Real GDP per capita; SI - percentage of skilled immigrants; USI - percentage of unskilled immigrants; SP - percentage of skilled population.

Notes: ${ }^{1}$ Based on a dynamic panel data model using system GMM estimators.

$2 *, * *, * * *$ denote significance at $10 \%, 5 \%$ and $1 \%$ level, $\mathrm{t}$ statistics in parenthesis.

${ }^{3}$ The null hypothesis of the Arellano and Bond test is the absence of residual autocorrelation.

The results of the Arellano and Bond test indicate no first-order correlation at $1 \%$ level and no secondorder correlation at $1 \%$ level.

${ }^{4}$ The overidentification of the model was tested using the Sargent test and the null hypothesis was rejected at $1 \%$ level indicating the model is not overidentified. 
The results (see Table 2 ) indicate that $\beta$-convergence rate is higher for the new EU member states than for the EU19 countries. This is consistent with the historical evolution of the GDP per capita growth rate for the two clusters. In the period 2007-2017, the average GDP per capita growth rate was 3.2 percent for Poland and 2.7 percent for Romania, compared with 0.97 percent in the case of Germany and 0.15 percent in the case of France. In terms of the impact of skilled and unskilled immigration on growth, the coefficients in the case of EU19 countries were statistically significant, while the coefficients for the non-EU19 countries were not. This is consistent with the main direction of the immigration flows and indicate that the EU19 countries are primarily attracting migrants and that they are the main beneficiaries of immigration.

To better understand the signs of the relationship between skilled and unskilled immigrants on one hand and the real GDP per capita growth on the other we have looked more closely at relevant factors that impact growth and which are related to the labour market. We have aim at understating the determinants of the unemployment rate. The underlining question behind the exercise was to see if immigration had a positive impact on the variables relevant for the labour market. Ideally, the sign of the relation between unemployment and immigration would be negative indicating that an increase in immigration would have a positive impact on the unemployment rate.

The results (please see Table 3 ) indicated that skilled immigration had a positive impact on the unemployment rate. In this vain, the negative sign of the coefficients suggests that an

Table 3. Testing the impact of skilled and unskilled immigration on unemployment ${ }^{1}$ (source: author own calculation)

Dependent variable: Ur

\begin{tabular}{|l|c|}
\hline $\mathrm{gGDPpercapita}_{t-1}$ & $\begin{array}{c}-0.352^{* * *} \\
(-3.23)\end{array}$ \\
\hline \multirow{2}{*}{$\mathrm{SI}_{t-1}$} & -3.99 \\
& $(-1.31)$ \\
\hline \multirow{2}{*}{$\mathrm{USI}_{t-1}$} & 2.24 \\
\multirow{2}{*}{$\mathrm{SP}_{t-1}$} & $(1.33)$ \\
\hline P-value for Arellano and Bond test for AR(1) & 1.79 \\
\hline P-value for Arellano and Bond test for AR(2) & $(1.45)$ \\
\hline P-value for Sargan test & 0.044 \\
\hline
\end{tabular}

Legend: Ur - unemployment rate; gGDPpercapita - Real GDP per capita growth; SI - percentage of skilled immigrants; USI - percentage of unskilled immigrants; SP - percentage of skilled population. Notes: ${ }^{1}$ Based on a dynamic panel data model using system GMM estimators.

$2 *, * *,{ }^{* *}$ denote significance at $10 \%, 5 \%$ and $1 \%$ level, $t$ statistics in parenthesis.

${ }^{3}$ The null hypothesis of the Arellano and Bond test is the absence of residual autocorrelation.

The results of the Arellano and Bond test indicate no first-order correlation at $10 \%$ level and potential second-order correlation (expected due to the lagged dependent variable).

${ }^{4}$ The overidentification of the model was tested using the Sargent test and the null hypothesis was rejected indicating the model is not overidentified. 
increase in immigration leads to a decrease of the unemployment rate. However, the impact of unskilled immigration is negative reflecting that after the economic crisis the sectors that hired unskilled immigration experienced a strong output decrease. The relationship between the skill level of the population and unemployment is also relevant. The sign of the coefficient in the case of skilled population is positive, reflecting that the countries with a higher share of skilled workers in the EU are also the countries which registered the lowest average GDP growth in the analyzed period with an impact on unemployment. These are the economies which are closer to the technological frontier and it is harder in these cases to generate productivity gains. Given the low $t$ values we have also considered the role of growth as an explanatory variable. The results of the model indicated the prevalent role of growth on unemployment. In our case GDP per capita captures the large array of factors that lead to an increase of the GDP per capita, as for example better institutions, more predictable fiscal and macroeconomic environment to name a few, which also positively impact the unemployment rate. The results suggest that the skill endowment alone does not have a significant impact on the unemployment rate, but a larger array of structural factors which impacts both unemployment and GDP per capita explains the decrease in the unemployment rate.

Given the possible heterogeneity between the countries in the European Union we have also tested the convergence club hypothesis in the case of the unemployment rate. The results (see Table 4) further substantiate the initial analysis (see Table 3). Economic growth had a

Table 4. Testing the impact of skilled and unskilled immigration on growth based on a dynamic panel model $^{1}$ for EU15 and the new EU member states (source: Author own calculation)

Dependent variable: Ur

\begin{tabular}{|l|c|c|}
\hline & EU15 member states & New EU member states \\
\hline \multirow{2}{*}{ gGDPpercapita $_{t-1}$} & -0.469 & $-0.331^{\star * *}$ \\
& $(-1.7)$ & $(-5.53)$ \\
\hline \multirow{2}{*}{$\mathrm{SI}_{t-1}$} & -6.15 & $-4.34^{\star * *}$ \\
& $(-0.95)$ & $(-4.33)$ \\
\hline \multirow{2}{*}{$\mathrm{USI}_{t-1}$} & $3.36^{*}$ & 0.857 \\
& $(1.92)$ & $(0.48)$ \\
\hline \multirow{2}{*}{$\mathrm{SP}_{t-1}$} & 6.01 & -0.089 \\
& $(1.16)$ & $0.12)$ \\
\hline -value for Arellano and Bond test for AR(1) & 0.445 & 0.186 \\
\hline P-value for Arellano and Bond test for AR(2) & 0.110 & 0.0 \\
\hline
\end{tabular}

Legend: Ur - unemployment rate; gGDPpercapita - Real GDP per capita growth; SI - percentage of skilled immigrants; USI - percentage of unskilled immigrants; SP - percentage of skilled population. Notes: ${ }^{1}$ Based on a dynamic panel data model using system GMM estimators.

$2 *, * *, * * *$ denote significance at $10 \%, 5 \%$ and $1 \%$ level, $\mathrm{t}$ statistics in parenthesis.

${ }^{3}$ The null hypothesis of the Arellano and Bond test is the absence of residual autocorrelation.

The results of the Arellano and Bond test indicate no first-order correlation at $10 \%$ level and potential second-order correlation (expected due to the lagged dependent variable).

${ }^{4}$ The overidentification of the model was tested using the Sargent test and the null hypothesis was rejected indicating the model is not overidentified. 
positive impact reducing unemployment for both clusters EU15 and the new EU member states. However, the coefficient is representative only in the latter case. This is consistent with the historical data which indicates a much stronger relation in the case of the new EU member states characterized by decreasing unemployment in a context of strong economic growth. In the case of the EU15 countries, the low average growth which followed the economic recession coincided with stubbornly high unemployment, mainly structural in nature. The signs of the coefficients in the case of immigration remain unchanged for the two supplementary models that we have tested. The value of the coefficient in the case of unskilled immigration is higher for the EU15 cluster reflecting the historical flows of unskilled immigrants from the new EU member states to EU15 countries.

\section{Conclusions}

Labour migration has supported over time the development of countries and regions. The approach to migration in the European Union varies, depending on the specific conditions in each country taking into account the integration opportunities of immigration flows.

In the European Union, immigrants are younger and have a higher level of education comparing to the national population, are more motivated, they move in order to earn more and are more productive in the receiving country compared with their country of origin (as result of knowledge, technologies, development, in general, and their desire to succeed).

The paper analysed the impact of immigration on growth and unemployment, taking into account the skill composition. We estimated six dynamic panel models using the system of generalized method of moments (GMM) to deal with the risk of an endogeneity bias of the migration variables. To control for the endogeneity bias, lagged values of the explanatory endogenous variable were used as instruments.

The results supported the role of the endowment with skills and abilities of the labour force in fostering economic growth. In this respect, we found a positive and significant impact of skilled immigration and skilled population on growth. We also found a $\beta$-convergence rate of 1.3 percent, consistent with the values found in the convergence literature which are around 2 percent.

Given the possible heterogeneity between the countries in the European Union we have also tested the convergence club hypothesis. The results indicated that the $\beta$-convergence rate is higher for the new EU member states than for the EU19 countries.

In order to better understand the relationship between skilled and unskilled immigrants on one hand and the economic growth (real GDP per capita) on the other, we also analysed the impact of immigration on relevant factors for the labour market. The results of the models showed a positive impact of skilled immigration on the unemployment rate. However, the values of the coefficients were not significant. Given the low t values we also considered the role of growth as an explanatory variable, which was captured by the real GDP per capita growth and proved to be significant. The results suggest that the skill endowment alone does not have a significant impact on the unemployment rate, but a larger array of structural factors which impacts both unemployment and GDP per capita explains the decrease in the unemployment rate. 
Concluding, immigration should be treated with openness by all the countries in European Union, in order to transform it from a threat as is seen by anti-migrant nationalists into an opportunity, which must be properly addressed considering that modern societies are facing aging population and shortage of skilled labour.

\section{Disclosure statement}

Authors do not have any competing financial, professional, or personal interests from other parties.

\section{References}

Ager, P., \& Bruckner, M. (2013). Cultural diversity and economic growth: Evidence from the US during the age of mass migration. European Economic Review, 64, 76-97. https://doi.org/10.1016/j.euroecorev.2013.07.011

Alesina, A., Harnoss, J., \& Rapoport, H. (2016). Birthplace diversity and economic prosperity. Journal of Economic Growth, 21(2), 101-138. https://doi.org/10.1007/s10887-016-9127-6

Algan, Y., Bisin, A., Manning, A., \& Verdier, T. (2013). Cultural integration of immigrants in Europe. Oxford University Press. https://doi.org/10.1093/acprof:oso/9780199660094.001.0001

Andersen, T., \& Dalgaard, C. J. (2011). Flows of people, flows of ideas, and the inequality of nations. Journal of Economic Growth, 16, 1-32. https://doi.org/10.1007/s10887-011-9060-7

Anderson, B., \& Blinder, S. (2017). Who counts as a migrants? Definitions and their consequences. Migration Observatory Briefing, COMPAS. University of Oxford, UK. January 2017. https://migrationobservatory.ox.ac.uk/wp-content/uploads/2016/04/Briefing-Who_Counts_Migrant.pdf

Armstrong, H. W., \& Read, R. (2002). The phantom of liberty? Economic growth and the vulnerability of small states. Journal of International Development, 14(4), 435-458. https://doi.org/10.1002/jid.886

Barro, R. J., \& Sala-i-Martin, X. X. (1992). Convergence. Journal of Political Economy, 100(2), 223-251. https://doi.org/10.1086/261816

Bell, M., Charles-Edwards, E., Ueffing, P., Stillwell, J., Kupiszewski, M., \& Kupiszewska, D. (2016). Internal migration and development: comparing migration intensities around the world. Population and Development Review, 41(1), 33-58. https://doi.org/10.1111/j.1728-4457.2015.00025.x

Bhagwati, J. (Ed.). (1982). Import competition and response. University of Chicago Press. https://doi.org/10.7208/chicago/9780226045405.001.0001

Bilan, Y. (2012). Specificity of border labour migration. Transformation in Business \& Economics, 11(2), 82-97.

Blossfeld, H. P., \& Mayer, K. U. (1988). Labor market segmentation in the Federal Republic of Germany: An empirical study of segmentation theories from a life course perspective. European Sociological Review, 4(2), 123-140. https://doi.org/10.1093/oxfordjournals.esr.a036472

Bødker, S., Jacobsen, R. H., \& Skaksen, J. R. (2013). Fiscal costs and benefits of high skilled immigration to a generous welfare state (Norface Migration Discussion Paper No. 2013-06). http://www.norface-migration.org/publ_uploads/NDP_06_13.pdf

Bodvarsson, O. B., \& Van den Berg, H. (2013). Economic growth and immigration. In The economics of immigration (pp. 217-248). Springer. https://doi.org/10.1007/978-1-4614-2116-0

Bonifazi, C., Okolzi, M., Schoorl, J., \& Simon, P. (2008). International migration in Europe. New trends and new methods of analysis. Amsterdam University Press. https://doi.org/10.1515/9789048501540 
Borjas, G. (1987). Self-selection and the earnings of immigrants. American Economic Review, 77(4), 531-553. https://doi.org/10.3386/w2248

Borjas, G. (1999a). Immigration and welfare magnets. Journal of Labor Economics, 17(4), 607-637. https://doi.org/10.1086/209933

Borjas, G. J. (1999b). The economic analysis of immigration. In O. Ashenfelter \& D. Card (Eds.), Handbook of labor economics (pp. 1697-1760). North Holland.

https://doi.org/10.1016/S1573-4463(99)03009-6

Boubtane, E., Dumont, J., \& Rault, C. (2014). Immigration and economic growth in the OECD countries, 1986-2006. (IZA Discussion Papers No. 8681). The Institute for the Study of Labor, Bonn, Germany. http://ftp.iza.org/dp8681.pdf

Bratsberg, B., Raaum, O., \& Roed, K. (2014). Immigrants, labour market performance and social insurance. Economic Journal, 124(580), 644-683. https://doi.org/10.1111/ecoj.12182

Brunow, S., Nijkam, P., \& Poot, J. (2015). The impact of international migration on economic growth in the global economy. In Handbook of the economics of international migration (Vol. 1, Chapter 19, pp. 1027-1075). Elsevier. https://doi.org/10.1016/B978-0-444-53768-3.00019-9

Burzynski, M. (2018). Time, space, and skills in designing migration policy. Journal of Demographic Econimics, 84(4), 355-417. https://doi.org/10.1017/dem.2018.5

Castles, S., \& Vezzoli, S. (2009). The global economic crisis and migration: temporary interruption or structural changes? Paradigmes, 2, June 2009.

Centre for Economic Performance London School of Economics. (2016, June). Brexit 2016. Policy analysis from the Center of Economic Performance. http://cep.lse.ac.uk/pubs/download/brexit08_book.pdf

Chiswick, B. R. (2000). Are immigrants favorably self-selected? An economic analysis. In C. D. Brettell \& J. F. Hollifield (Eds.), Migration theory: Talking across the disciplines (pp. 56-72). Routledge Press.

Chiswick, B. R., \& Hatton, T. (2003). International migration and the integration of labor markets. In M. D. Bordo, A. M. Taylor, \& J. G. Williamson, Globalization in historical perspective. University of Chicago Press. https://doi.org/10.7208/chicago/9780226065991.003.0003

Constant, A. (2014). Do migrants take the jobs of natives workers? IZA World of Labor. https://doi.org/10.15185/izawol.10

Coulter, S. (2018). Skillformation, immigration and European intergration: The politics of the UK growth model. New Political Economy, 23(2), 208-222. https://doi.org/10.1080/13563467.2017.1370446

Cuadros, A., Martin-Montaner, J., \& Paniagua, J. (2019). Migration and FDI: The role of job skills. International Review of Economics \& Finance, 59, 318-332. https://doi.org/10.1016/j.iref.2018.09.007

Dinu, M., Marinas, M. C., Socol, C., \& Socol, A. (2012). Clusterization, persistence, dependency and volatility of business cycles in an enlarged euro area. Romanian Journal of Economic Forecating, 15(2), 5-23. http://www.ipe.ro/rjef.htm

Dinu, V., Grosu, R. M., \& Săseanu, A. S. (2015). Romanian immigrant entrepreneurship: Utopia or reality? An overview of entrepreneurial manifestations of Romanian immigrants in Andalusia, Spain. Transformations in Business \& Economics Journal, 14(1), 48-64.

Dobson, J. R., \& Sennikova, I. (2007). From fundamental freedom to political and economic 'hot potato' in 50 years: Labour mobility and migration within the EU. Journal of Business Economics and Management, 8(2), 123-136. https://doi.org/10.3846/16111699.2007.9636160

Doeringer, P. B., \& Piore, M. (1971). Internal labor markets and manpower analysis. Lexington Books.

Dolado, J., Goria, A., \& Ichino, A. (1994). Immigration, human capital and growth in the host country: Evidence from pooled country data. Journal of Population Economics, 7, 193-215.

https://doi.org/10.1007/BF00173619 
Dustmann, C., \& Gorlach, J. S. (2016). Estimating immigrant earnings profiles when migrations are temporary. Labour Economics, 41, 1-8. https://doi.org/10.1016/j.labeco.2016.05.023

Dustmann, C., \& Frattini, T. (2013). Immigration: The European experience (IZA Discussion Papers No. 6261). The Institute for the Study of Labor, Bonn, Germany. http://ftp.iza.org/dp6261.pdf

Dustmann, C., Glitz, A., \& Frattini, T. (2008). The labour market impact of immigration (Discussion Paper Series, CDP No. 11/08). Centre for Research and Analysis of Migration, London, UK. https://doi.org/10.1093/oxrep/grn024

European Commission. (2017). COMM. 10 trends shaping migration. European Commission. European Political Strategy Center, Bruxelles.

European Investment Bank. (2016). Migration in the EU. Challenges, opportunities and the role of EIB. Luxembourg. https://www.eib.org/attachments/migration_and_the_eu_en.pdf

European Movement International. (2016a). Free Movement and Schengen. A No Borders Europe. http:// europeanmovement.eu/wp-content/uploads/2016/06/EMI_16_PolicyPosition_17_VIEW_Schengen_FINAL.pdf

European Movement International. (2016b). Migration and the refugees crisis. A European response. http://europeanmovement.eu/wp-content/uploads/2016/04/EMI_16_PolicyPosition_MIGRATION_VIEW_FINAL.pdf

Etzo, I. (2008). Internal migration: A review of the literature (MPRA Paper No. 8783).

Eurostat Statistics. (2017). Migration and citizenship data. http://ec.europa.eu/eurostat/web/populationdemography-migration-projections/migration-and-citizenship-data

Fassio, C., Montobbio, F., \& Venturini, A. (2019). Skilled migration and innovation in European industries. Research Policy, 48(3), 706-718. https://doi.org/10.1016/j.respol.2018.11.002

Favell, A. (2008). The new face of East-West migration in Europe. Journal of Ethnic and Migration Studies, 34(5), 701-716. https://doi.org/10.1080/13691830802105947

Felbermayr, G., Hiller, S., \& Sala, D. (2010). Does immigration boost per capita income? Economics Letters, 107, 177-179. https://doi.org/10.1016/j.econlet.2010.01.017

Fix, M., Papademetriou, D. G., Batalova, J., Terrazas, A., Lin, S. Y., \& Mittelstadt, M. (2009). Migration and the Great Recession. Migration Policy Institute, Washington, DC.

Fratesi, U., \& Riggi, R. M. (2007). Does migration reduce regional disparities? The role of skill-selective flows. Review of Urban and Regional Development Studies, 19(1), 78-102. https://doi.org/10.1111/j.1467-940X.2007.00125.x

Friedberg, R. M. (2000). You can't take it with you? Immigrant assimilation and the portability of human capital. Journal of Labor Economics, 18(2), 221-251. https://doi.org/10.1086/209957

Fuest, C., \& Thum, M. (1999). Welfare effects of immigrațion in a dual labor market (CESifo Working Paper No. 2015). Munich, Germany. https://www.cesifo-group.de/pls/guestci/download/F4490/ MT_UNION2.PDF

Garcia-Rodriguez, Y., Mihi-Ramirez, A., \& Navarro-Pobsdorf, M. (2015). Highly-skilled migration, migrant networks and the prestige of academic institutions. Inzinerine Ekonomika-Engineering Economics, 26(5), 500-506. https://doi.org/10.5755/j01.ee.26.5.12463

Gathmann, C. (2015). Naturalization and citizenship: Who benefits? IZA World of Labor. https://doi.org/10.15185/izawol.125

Green, C., Kler, P., \& Leeves, G. (2007). Immigrant overeducation: Evidence from recent arrivals to Australia. Economics of Education Review, 26(4), 420-432. https://doi.org/10.1016/j.econedurev.2006.02.005

Grossmann, V. (2016). How immigration affects investment and productivity in host and home countries. IZA World of Labor. https://doi.org/10.15185/izawol.292 
Herm A., \& Poulain, M. (2012). Economic crisis and International Migration. What the EU data reveals? Revue Europeenne des Migrations Internationales, 28(4), 145-169.

https://doi.org/10.4000/remi.6171

International Organization of Migration. (2017). World Migration Report 2018. Geneva. https://www. iom.int/sites/default/files/country/docs/china/r5_world_migration_report_2018_en.pdf

Josifidis, K., Supic, N., Pucar, E. B., \& Srdic, S. (2014). Labour migration flows: EU8+2 vs EU-15. Journal of Business Economics and Management, 15(1), 41-55.

https://doi.org/10.3846/16111699.2013.841283

Kahanec, M., \& Kurekova, L. (2014). Did post-enlargement labor mobility help the EU to adjust during the great recession? The case of Slovakia (Discussion Paper No. 8249). The Institute for the Study of Labor. http://ftp.iza.org/dp8249.pdf

Kalaitzidakis, P., Mamuneas, T. P., Savvides, A., \& Stengos, T. (2001). Measures of human capital and nonlinearities in economic growth. Journal of Economic Growth, 6(3), 229-254. https://doi.org/10.1023/A:1011347816503

Kanbur, R., \& Rapoport, H. (2005). Migration selectivity and the evolution of spatial inequality. Journal of Economic Geography, 5(1), 43-57. https://doi.org/10.1093/jnlecg/lbh053

Kemnitz, A. (2003). Unemployment, technology and the welfare effects of immigration (Discussion papers). https://ub-madoc.bib.uni-mannheim.de/1000/1/611.pdf

Kumpikaite, V., \& Zickute, I. (2012). Synergy of migration theories: Theoretical insights. Inzinerine Ekonomika-Engineering Economics, 23(4), 387-397. https://doi.org/10.5755/j01.ee.23.4.1240

Lofstrom, M. (2014). Immigrants and entreprenuership. IZA World of Labor.

Lu, H., Yue, A. L., Chen, H., \& Long, R. Y. (2018). Could smog pollution lead to the migration of local skilled worked? Evidence from the Jing-Jin-Ji region in China. Resources Conservation and Recycling, 130, 177-187. https://doi.org/10.1016/j.resconrec.2017.11.024

Mandelman, F. S., \& Zlate, A. (2017). The socio-economic impact of migration flows: Effects on trade, remittances, output, and the labour market. International Finance, 20(1), 100-112. https://doi.org/10.1111/infi.12105

Mankiw, N. G., Romer, D. H., \& Weil, D. N. (1992). A Contribution to the empirics of economic growth. Quarterly Journal of Economics, 107(2), 407-437. https://doi.org/10.2307/2118477

Markaki, Y., \& Longhi, S. (2012). What determines attitudes to immigration in European countries? An Analysis at the regional level (Norface Migration Discussion Paper No. 2121-32).

McCann, P. (2001). Urban and regional economics. Oxford Publishing.

Mihi-Ramirez, A., Garcia-Rodriguez, Y., \& Cuenca, E. (2016). Innovation and international high skilled migration. Inzinerine Ekonomika-Engineering Economics, 27(4), 452-461.

https://doi.org/10.5755/j01.ee.27.4.14396

Mihi-Ramirez, A., Kumpikaite-Valiuniene, V., \& Cuenca-Garcia, E. (2017). An inclusive analysis of determinants of international migration. The case of European rich and poor countries. Technological and Economic Development of Economy, 23(4), 608-626. https://doi.org/10.3846/20294913.2017.1306726

Mol, C., \& Valk, H. (2016). Migration and immigrants in Europe: A historical and demographic perspective. In B. Garces-Mascarenas \& R. Penninx (Eds.), Integration processes and policies in Europe. Springer International Publishing.

Müller, T. (1997). Migration, dual labour markets and social welfare in a small open economy. Cahier 97-13 du Centre de Recherche en Economie et Finance Appliquees CREFA (pp. 34-68). In R. Faini, J. de Melo, \& K. F. Zimmermann (Eds.), Migration: The controversies and the evidence. Cambridge University Press. http://archive-ouverte.unige.ch/unige:35477 
Naumann, E., Stoetzer, L. F., \& Pietrantuono, G. (2018). Attitude towards highly skilled and low-skilled immigration in Europe: A survery experiment in 15 European countries. European Journal of Political Research, 57(4), 1009-1030. https://doi.org/10.1111/1475-6765.12264

Newbold, K. B. (2019). Short-term relocation versus long-term migration: Implications for economic growth and human capital change. Population Space and Place, 25(4), e2211. https://doi.org/10.1002/psp.2211

Nijkamp, P., \& Poot, J. (1998). Spatial perspectives on new theories of economic growth. Annals of Regional Science, 32(1), 7-37. https://doi.org/10.1007/s001680050061

Oberman, K. (2015). Poverty and immigration policy. American Political Science Review, 109(2), 239251. https://doi.org/10.1017/S0003055415000106

Official Journal of European Union. (2007). Regulation (EC) No 862/2007 of the European Parliament and The Council of 11 July 2007 on Community statistics on migration and international protection and repealing Council Regulation (EEC) No 311/76 on the compilation of statistics on foreign workers. https://eur-lex.europa.eu/legal-content/EN/TXT/HTML/?uri=CELEX:32007R0862\&qid=1448 964364407\&from $=\mathrm{EN}$

Ogawa, H., \& Tsubuku, M. (2017). Impact of capital market integration on skilled-unskilled labour choice. Journal of Economic Integration, 32(1), 90-111. https://doi.org/10.11130/jei.2017.32.1.90

Orefice, G. (2010). Skilled migration and economic performances: Evidence from OECD countries. Swiss Journal of Economics and Statistic, 146, 781. https://doi.org/10.1007/BF03399337

Ozgen, C., Nijkamp, P., \& Poot, J. (2009). The effect of migration on income growth and convergence: meta-analytic evidence. (IZA Discussion Paper No. 4522). Institute for the Study of Labor. http://ftp.iza.org/dp4522.pdf

Peković, D. (2017). The effects of remittances on poverty alleviation in transition countries. Journal of International Studies, 10(4), 37-46. https://doi.org/10.14254/2071-8330.2017/10-4/2

Peri, G. (2014). Do immigrants workers depress the wages of native workers? (pp. 1-42). IZA World of Labor. https://doi.org/10.15185/izawol.42

Piore, J. (1979). Birds of passage: Migrant labor and industrial societies. Cambridge University Press. https://doi.org/10.1017/CBO9780511572210

Popescu, C. R., Popescu, G. N., \& Popescu, A.V. (2017). International migration, attempting to create a better world - A case study on Romania's situation (pp. 93-104). In Proceedings of the $29^{\text {th }}$ International Business Information Management Association (IBIMA), Vienna, Austria.

Preston, I. (2013). The effect of immigration on public finances. Centre for research and analysis of migration CReAM (Discussion Paper Series CDP No. 23/13). http://cream-migration.org/publ_uploads/ CDP_23_13.pdf

Rappaport, J. (2005). How does labor mobility affect income convergence? Journal of Economic Dynamics \& Control, 29(3), 567-581. https://doi.org/10.1016/j.jedc.2004.03.003

Rica, S., Glitz, A., \& Ortega, F. (2013). Immigration in Europe: Trends, policies and empirical evidence (IZA Discussion Paper No. 7778). The Institute for the Study of Labor, Bonn, Germany.

Rivas, M. D. G., \& Villarroya, I. S. (2016). Testing the convergence hypothesis for OECD countries: A reappraisal (Economics Discussion Papers, No. 2016-45). Kiel Institute for the World Economy. http://www.economics-ejournal.org/economics/discussionpapers/2016-45

Roman, M., \& Voicu, C. (2010). Some socio-economic effects of labor migration on sending countries. Evidence from Romania. Theoretical and Applied Economics, 17(7(548)), 61-76. http://store.ectap.ro/articole/484.pdf

Roodman, D. (2006) How to do xtabond2: An introduction to 'Difference' and 'System' GMM in Stata (Working Paper No. 103). Center for Global Development. https://doi.org/10.2139/ssrn.982943 
Sala-i-Martin, X. X. (1996). Regional cohesion: Evidence and theories of regional growth and convergence. European Economic Review, 40, 1325-1352. https://doi.org/10.1016/0014-2921(95)00029-1

Sanroma, E., Ramos, R., \& Simon, H. (2015). Portability of human capital and immigrants overeducation in Spain. Population Research and Policy Review, 34(2), 223-241. https://doi.org/10.1007/s11113-014-9340-y

Sturge, G. (2018). Briefing paper Number SN06077, Dec. 2018, Migration Statistics. The House of Commons Library, UK.

United Nations. (2011). Impact of remittances on poverty in developing countries. New York and Geneva. https://unctad.org/en/docs/ditctncd20108_en.pdf

Wadsworth, J. (2015). Immigration and the UK labour market. Center for Economic Performance, London. http://cep.lse.ac.uk/pubs/download/EA019.pdf

Warman, C., Sweetman, A., \& Goldmann, G. (2015). The portability of new immigrants' human capital: language, education, and occupational skills. Canadian Public Policy [Analyse de Politique], 41(suppl. 1), 64-79. https://doi.org/10.3138/cpp.2013-055

Wilkinson, E., Kirbyshire, A., Mayhew, L., Batra, P., \& Milan, A. (2016). Climate-induced migration and displacement: Closing the policy gap. Overseas Development Institute, London. 